\title{
The olfactory reference syndrome treated with escitalopram: A case report
}

\author{
Essitalopram ile tedavi edilen bir olfaktör referans sendromu : Bir olgu sunumu
}

Özlem Devrim BALABAN, Gizem BOZ, Kumru ŞENYAŞAR, Menekşe Sıla YAZAR, Ali KEYVAN, Nezih ERADAMLAR

\begin{abstract}
Olfactory reference syndrome (ORS) is a clinical condition that causes patients to be excessively anxious about emitting body odors that may be offensive for other people. This causes heavy distress and depression, even leading to suicides. The ORS is classifised under different categories.

In this paper, we report a patient with ORS. She has a preoccupation of foul body odor emanating from her anal region which we treated with escitalopram. We also discuss, within the framework of this case, the place of ORS in systems of clinical classified and in literature.
\end{abstract}

Keywords: Olfactory reference syndrome, Classification, Treatment

\section{ÖZET}

Olfaktör referans sendromu (ORS), hastaların diğer insanlar için rahatsız edici olabilecek nitelikte kötü kokular yaydıkları konusunda oldukça endişeli olduğu klinik bir durumdur. Bu durum, şiddetli stres ve depresyona sebep olup, intihara bile yol açabilmektedir. Olfaktör referans sendromu, siniflandirma sistemlerinde ve literatürde farklı kategoriler altında değerlendirilmektedir.

$\mathrm{Bu}$ yazıda, essitalopram ile tedavi edilen, anal bölgesinden kaynaklanan kötü kokular yaydığına dair preoküpasyonları olan bir ORS vakasını ve bu vaka çercevesinde ORS'nu, sınıflandırma

Özlem Devrim Balaban (区), Ali Keyvan

Forensic Unit, Neurology and Neurosurgery Clinic, Bakırköy Training and Research Hospital for Psychiatry, Istanbul, Turkey e-mail.ozlemdevrimbalaban@gmail.com

Gizem Boz

Maternity Unit, Zeynep Kamil Training and Research Hospital for Maternity and Children's Diseases, Istanbul, Turkey

Kumru Şenyaşar, Menekşe Sila Yazar, Nezih Eradamlar

12th Psychiatry Unit, Neurology and Neurosurgery Clinic, Bakırköy

Training and Research Hospital for Psychiatry, Istanbul, Turkey

Submitted/Gönderilme: 13.02 .2015

Accepted/Kabul: 01.04.2015 sistemlerinde ve literatürde farklı kategoriler altında tartıştık.

Anahtar kelimeler: Olfaktör referans sendromu, Sinıflandırma, Tedavi

\section{Introduction}

Olfactory reference syndrome (ORS) is a clinical condition that causes patients to be anxious about emitting body odors that may be offensive for other people [1].

Patients with ORS react regretfully because they feel shame for being, as they believe, the cause of the smell [1]. This situation causes heavy distress and depression, even suicides [2].

The International Classification of Diseases (ICD)-10 referred to ORS in the section of delusional disorders. In The Diagnostic and Statistical Manual of Mental Disorders (DSM)-III's 1980 North American edition, it was ranked among atypical somatomorphic disorders. The classification of ORS was changed to somatic delusional disorder in the DSM-IV and it classified in the same way [3].

ORS is treated with antipsychotics, antidepressants or combinations of both. [4]. In some studies, authors reported that the patients did not respond to antipsychotics, but responded to the selective serotonin reuptake inhibitors (SSRI). There are also case reports about patients that are treated with tricyclic antidepressants [5].

In this paper, we report a case with ORS which we treated with escitalopram.

\section{Case Report}

Miss Y was a 22 year old university student living in a student hostel. The patient was admitted to the psychiatry 
department for a gastroenterology consultation. She said that she had a foul body odor, the smell emanated from her anal region as a result of gas and faecal incontinence. She emphasized that people reacted to this foul odor.

Her complaints started 2 months earlier. She said that one day when she entered the class; she felt a foul odor and someone from the classroom said "It smells so bad". She added that since then she frequently perceived that foul odor resembling the odor of gas or faeces and started to think that the odor might emanate from her body. There actually was no significant odour. She had started to wash frequently, check her underwear for faecal stains, and change her clothing often, but had realized that a foul odor still emanated from her body. She added that the severity and the frequency of this foul odor had increased for the last month and that people recognized this odor, looked at her strangely, and said something like "Smelling very bad". She stated that she felt shame and embarrassment about her foul body odor and as a result of this, avoided more and more social interactions and started to miss days at school. She had become anxious and demoralized and started to suffer from insomnia. She decided to drop out the school.

According to the psychiatric examination, her self care was adequate. Her clothing was compatible with her sociocultural situation and was avoiding eye contact from time to time. She was in cooperation with the physician. Her affect was very anxious and her mood was depressive. She cried continuously during the interview. Her thoughts were logically associated and goal directed. In the content of her thought there was a preoccupation with the idea that she smelled of faeces and gas because of a defect at her anal sphincter causing incontinence. Additionally, she had referential ideas as other people recognized the odor. There was no other thought disturbances except this preoccupation and related ideas. There was no hallucination or illusion. The test judgment, memory and concentration of the patient were adequate. Her insight was considered as poor to the illness.

Her thoughts about the foul body odor and incontinence were considered as a preoccupation, not a delusion, as she said that she was not $100 \%$ certain about this idea on close questioning. Also she easily accepted the psychotropic medication and stopped to seek help from other departments like gastroenterology.

There was no history of classic obsessions or compulsions or of any definite hallucinations or delusions. There was no history of substance abuse or of an underlying general medical disorder or another psychiatric disorder. There was no family history of any psychiatric disorder. She was defining her premorbid personality traits as sensitive, exacting, introvert and compatible in social relationships.

The electroencephalography, computed tomography, B12, folate, complete blood count, urinalysis, and liverkidney-thyroid function test were normal.

The patient was treated with escitalopram $10 \mathrm{mg}$ daily. She showed a gradual reduction in her preoccupations about odors and depressive symptoms. As the patient's symptoms (obsessions as intrusive thoughts about body odor, compulsions as repetitive cleansing and avoidance behaviors) were reminding the obsessive compulsive disorder (OCD) with poor insight according to DSM-IV [6], we decided to follow up the course of ORS symptoms with Yale Brown Obsessive-Compulsive Rating Scale like some researchers in the literature [7]. At the beginning of the treatment the rating for her depressive symptoms on the Hamilton Depression Rating Scale was 35 and of her rating for preoccupation and related behaviors on the Yale Brown Obsessive-Compulsive Rating Scale was 27. Four weeks later the scores fell to 20 and 16, eight weeks later fell to 7 and 8 respectively. The patient was treated with escitalopram for twelve months with remission. Then the pharmacotherapy was stopped. The follow up continued for one more year without medication. Symptoms remained significantly improved throughout this time.

\section{Discussion}

The mean age at ORS onset in the literature is the early or mid 20s [3], but some researchers have found a mean onset of $15.6 \pm 5.7$ years [7]. The age onset of ORS symptoms in our patient was 22 years which was similar to the literature.

Depression was often reported to be diagnosed as a comorbid disorder in patients with ORS [8,9]. Pryse-Philips [1], reported 36 ORS patients with severe depression symptoms which began after onset of ORS. In a crosssectional study, the authors reported that they determined depressive symptoms in nearly three quarters of their ORS sample which they considered to be secondary to ORS [7]. Smilar to the literature, our patient had severe depression symptoms which we considered to be primarily due to ORS. Although, depression is reported to be the most common comorbid disorder in ORS, ORS may be comorbid with other disorders like schizophrenia, bipolar disorders, substance use disorders, social fobia, OCD, and body dismorfic disorder (BDD) $[1,7]$. In our patient, there was no other comorbid 
psychiatric disorder except depression.

Although, patient's beliefs about emiting foul body odor are often suggested to be delusional in ORS $[9,10]$, some authors have noted that these beliefs are not always delusional $[3,11,12]$. In a recent research, twenty patients with ORS were systematically assessed using semi-structured measures and it was found to be that most patients (85\%) had delusional beliefs, whereas $15 \%$ had poor or fair insight [7]. According to another research only $21 \%$ of 14 patients' beliefs were delusional [12]. We assessed our patient's beliefs as preoccupational, not delusional, with poor insight as she said that she was not $100 \%$ certain about this idea on close questioning. and easily accepted the psychotropic medication and stopped to seek help from other departments like gastroenterology.

Pryse-Philips [1] indicated that almost all of the patients with ORS had lifetime ideas or delusions of reference involving misinterpreting other people's comments or behaviors as confirmed by other authors $[5,7,9]$. Our patient had also referential thinking as other people looked at her strangely and said something like "It smells very bad" and realized the odor.

It is reported that excessive repetitive behaviors often accompany with ORS symptoms [5,7,12]. The purpose of these behaviors is eliminating, checking, obtaining reassurance about, or masking the perceived foul body odor thought to be emanating from the patient's body [7]. Furthermore, Stein et al.[5] indicate that symptoms related to body odor met the DSM-IV [6] criteria for obsessions ( intrusive thoughts about body odor) and compulsions (repetitive cleansing behaviors) with poor insight. Also, avoidance behavior is typical in ORS [1]. In this context, our patient's symptoms like preoccupations about her body odor and repetitive behaviors as washing up and changing her clothing frequently and checking her underwear, were overlapping with OCD. Additionally, there are reported cases in the literature treated with SSRI treatment $[5,13]$ and cognitive behavioral therapy [14] which are well known to be effective in OCD. Our patient was also treated with SSRI, escitalopram, which improved the symptoms significantly. Stein et al. [5] suggest to make systematic studies with larger samples of patients with ORS to determine whether ORS is best viewed as an OCD spectrum disorder or not.

Consequently, ORS is a rare psychiatric disorder with a poor functional overcome when untreated, so it is important to diagnose these patients with ORS and know different treatment modalities. Its place in classification systems and literature is controversial. Further studies regarding symptoms, treatment and outcome are needed to fully determine this disease.

\section{References}

1. Pryse-Phillips W. An olfactory reference syndrome. Acta Psychiatr Scand 1971;47:484-509.

2. Munro A. Monosymptomatic hypochondriacal psychosis. Br J Psychiatry Suppl. 1988 Jul; (2):37-40.

3. Begum M, McKenna PJ. Olfactory reference syndrome: a systematic review of the world literature. Psychol Med 2011;41:453-61. doi: 10.1017/S0033291710001091.

4. Cruzado L, Cáceres-Taco E, Calizaya JR. Apropos of an Olfactory Reference Syndrome case. Actas Esp Psiquiatr 2012; 40:234-8

5. Stein DJ, Le Roux L, Bouwer C, Van Heerden B. Is olfactory reference syndrome an obsessive-compulsive spectrum disorder? Two cases and a discussion. J Neuropsychiatry Clin Neurosci 1998;10:96-9.

6. American Psychiatric Association: Diagnostic and Statistical Manual of Mental Disorders, 4th edition. Washington, DC: American Psychiatric Association, 1994.

7. Phillips KA, Menard W. Olfactory reference syndrome: demographic and clinical features of imagined body odor. Gen Hosp Psychiatry 2011;33:398-406. doi: 10.1016/j. genhosppsych.2011.04.004.

8. Phillips KA, Gunderson C, Gruber U. Delusions of body malodour; the olfactory reference syndrome. In: Brewer W, Castle D, Pantelis C, editors. Olfaction and the Brain. New York:Cambridge: University Press, 2006:34-353.

9. Puşuroğlu M, Kandemir G, Hocaoğlu Ç. Ergende olfaktör referans sendromu: Bir olgu sunumu. JMOOD 2014; 4:41-3. doi: $10.5455 /$ jmood.20131119012825.

10. Bizamcer AN, Dubin WR, Hayburn B. Olfactory reference syndrome. Psychosomatics 2008; 49:77-81. doi: 10.1176/appi. psy.49.1.77.

11. Suzuki K, Takei N, Iwata Y, et al. Do olfactory reference syndrome and jiko-shu-kyofu (a subtype of taijin-kyofu) share a common entity? Acta Psychiatr Scand 2004;109:150-5. doi: 10.1046/j.1600-0447.2003.00195

12. Prazeres AM, Fontenelle LF, Mendlowicz MV, et al. Olfactory reference syndrome as a subtype of body dysmorphic disorder. J Clin Psychiatry 2010 ;71:87-9. doi: 10.4088/JCP.09105040.

13. Teraishi T, Takahashi T, Suda T, et al. Successful treatment of olfactory reference syndrome with paroxetine. J Neuropsychiatry Clin Neurosci 2012 ;24:E24. doi:10.1176/ appi.neuropsych.11020033.

14. Martin-Pichora AL, Antony MM. Successful treatment of olfactory reference syndrome with cognitive behavioral therapy: A case study. Cognitive and Behavioral Practice 2011;18: 545-54. doi: 10.1016/j.cbpra.2010.11.007. 